\title{
Deklaracja z San Francisco nt. Oceny Badań Naukowych (DORA): czy to początek końca dotychczasowej metody oceny parametrycznej?
}

\author{
Edward Towpik
}

\section{Sand Francisco Declaration on Research Assessment (DORA)}

Inicjatorem The San Francisco Declaration on Research Assessment (DORA) jest American Society for Cell Biology (ASCB) oraz międzynarodowa grupa przedstawicieli środowisk naukowych redaktorów i wydawców czasopism naukowych (editors and publishers of scholarly journals). Widzą oni pilną potrzebę zmiany dotychczasowego sposobu oceniania wyników badań naukowych i dorobku poszczególnych badaczy, a przede wszystkim - odrzucenia dominującej roli niewłaściwie stosowanego i błędnie interpretowanego czynnika wpływu lub, jak kto woli — czynnika oddziaływania (Impact Factor).

Problem ten nie od dziś budzi niepokój środowisk naukowych [1-5 i in.]. Zwracaliśmy nań uwagę również w naszym piśmie [6-8].

Projekt Declaration on Research Assessment (DORA) powstał w San Francisco podczas ASCB Annual Meeting w 2012 roku i wywołał żywy oddźwięk zarówno w środowisku, jak i w specjalistycznym piśmiennictwie. Przedstawiana tu obecnie wersja uwzględnia szereg uzupełnień i poprawek zgłoszonych przez zainteresowane strony.

Pierwszymi sygnatariuszami (original signers) Deklaracji było 155 wybitnych przedstawicieli świata nauki - członków towarzystw, instytucji naukowych i redakcji (wśród nich np. Bruce Alberts — redaktor naczelny Science, i b. prezes amerykańskiej National Academy of Sciences, Sir Paul Nurse - prezydent The Royal Society i laureat Nagrody Nobla w 2001 r. za badania nad regulacją cyklu komórkowego, Sir Tom Hunt — odkrywca cyklin i laureat Nagrody Nobla w 2001 r., Sir John Gurdon - laureat Nagrody Nobla w dziedzinie medycyny w 2012 r.) oraz 82 sygnatariuszy instytucjonalnych (m.in. Public Library of Science PLOS, American Association for the Advancement of Science czy Wellcome Trust). Można uznać ich za współinicjatorów DORA.

Obecnie Deklaracja jest już sygnowana przez 9596 osób i 409 instytucji [9].
Do indywidualnych original signers należą m.in.:

- Bruce Alberts, Editor-in-Chief, Science, Past President, National Academy of Sciences

- David Botstein, Founding Editor-in-Chief, Molecular Biology of the Cell

- Helga Novotny, President, European Research Council

- Sharon Ahmad, Executive Editor, Journal of Cell Science

- Simeon Arseniyadis, Research Director, CNRS-France

- Stefano Bertuzzi, Executive Director, American Society for Cell Biology

- Ted Bianco, Acting Director, Wellcome Trust

- Julio E. Celis, Editor-in-Chief, Molecular Oncology

- Howy Jacobs, Chief Editor, EMBO Reports

- Liz Williams, Executive Editor, The Journal of Cell Biology

- Mitsuhiro Yanagida, Editor-in-Chief, Genes to Cells

- Mark Johnston, Editor-in-Chief, Genetics

- Jordan Raff, President, British Society of Cell Biology; Editor-in-Chief, Biology Open; Professor, Cancer Cell Biology, University of Oxford.

- Noel B. Salazar, President, European Association of Social Anthropologists Marlowe Tessmer, Senior Editor, The Journal of Experimental Medicine

- Inder Verma, Editor-in-Chief, Proceedings of the National Academy of Sciences

- Michael Way, Editor-in-Chief, Journal of Cell Science

- Daniel Louvard, Director of the Research Centre, Institut Curie

- Michael Lynch, President, Genetics Society of America

- Tom Misteli, Editor-in-Chief, The Journal of Cell Biology

- Paul Nurse President, The Royal Society

- Richard N. Perham, Editor-in-Chief, FEBS Journal

- Edward N. Pugh, Jr. Editor, Journal of General Physiology

- Bernd Pulverer, Chief Editor, The EMBO Journal; Head of Scientific Publications, EMBO

- Don Cleveland, President, American Society for Cell Biology 
- Stephen Curry, Professor and Chair, Department of Life Sciences, Imperial College, London

- László Fésüs, Chairman of Publications Committee, Federation of European Biochemical Societies

- Marty Frank, Executive Director, The American Physiological Society

- Fernando Garzon President, ECS - The Electrochemical Society

- Alexander Gerber, Managing Director, German Research Center for Science \& Innovation Communication

Wśród instytucjonalnych original signers znalazły się m.in.:

- American Association for the Advancement of Science

- British Society for Cell Biology

- American Society for Cell Biology

- Wellcome Trust

- European Association of Science Editors

- Howard Hughes Medical Institute

- Federation of European Biochemical Societies

- Higher Education Funding Council for England

- FEBS Journal

- FEBS Letters

- FEBS Open Bio

- Journal of Cell Science

- Journal of Neurochemistry

- Proceedings of The National Academy Of Sciences

- Public Library of Science (PLOS)

- The EMBO Journal

- The International Society of Addiction Journal Editors

- The Journal of Cell Biology

- The Journal of Experimental Biology

- The Macfarlane Burnet Institute for Medical Research and Public Health

- Swiss Academy of Medical Sciences

- The American Physiological Society

- The Anatomical Record

- The Association of Australian Medical Research Institutes

- Molecular Oncology
- Molecular Biology of the Cell

- Molecular Systems Biology

- European Association of Social Anthropologists

- European Astronomical Society (EAS)

- European Atherosclerosis Society (EAD)

- European Council of Doctoral Candidates and Junior Researchers (EURODOC)

- European Glaucoma Society

- European Mathematical Society

- European Society for the History of Science

- European Sociological Association

Będziemy śledzić postępy prac nad zmianami sposobów oceny wyników badań naukowych i informować o nich Czytelników Nowotworów.

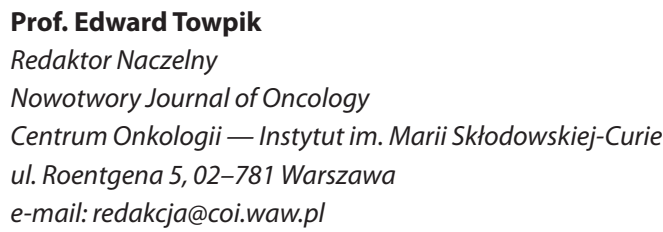

\section{Piśmiennictwo}

1. Seglen PO. Why the impact factor of journals should not be used for evaluating research? BMJ 1997; 314: 498-502.

2. European Association of Science Editors. The EASE statement on the inappriopriate use of impact factors. www.ease.org.uk/publications/impact-factors-statement

3. Macilwain C. Halt the avalanche of performance metrics. Nature 500; 255 (15 August 2013) doi:10.1038/500255a.

4. Baum J. Free-riding on power laws: questioning the validity of the impact factor as a measure of research quality in organization studies. Organization 2011; 18: 449-466

5. Bornman L, MarxW, Gasparyan AY i wsp. Diversity, value and limitations of the journal impact factor and alternative metrics. Rheumatol Int 2012; 32: 1861-1867.

6. Jadacki J. Czy Kopernik zasługiwałby na tytuł profesorski? O tym, jak oceniać naukowców. Nowotwory J Oncol 2012; 62: 134-138.

7. Oświadczenie Europejskiego Stowarzyszenia Redaktorów Naukowych (European Association of Science Editors - EASE) w sprawie niewłaściwego stosowania wskaźników oddziaływania (IF, impact factors). Nowotwory J Oncol 2012; 62: 139-140.

8. Wróblewski AK. Czas wrócić do rozsądku. Nowotwory J Oncol 2013; 63: 66-67.

9. http://am.ascb.org/dora/.

\section{San Francisco Declaration on Research Assessment Putting science into the assessment of research (tekst)}

Zachodzi pilna potrzeba, aby udoskonalić sposoby oceniania wyników badań naukowych, dokonywane przez organizacje finansujące, instytucje akademickie i inne zainteresowane strony.

W tym celu grupa redaktorów i wydawców czasopism naukowych spotkała się 16 grudnia 2012 roku, podczas corocznego spotkania American Society for Cell Biology (ASCB) w San Francisco w Kalifornii. Zespół ten opracował zestaw zaleceń, nazwanych później San Francisco Declaration on Research Assessment.Zwracamy się do zainteresowanych stron reprezentujących wszystkie dyscypliny naukowe o okazanie wsparcia przez dopisanie się do listy sygnatariuszy Deklaracji. 
Ilość uzyskiwanych wyników badań naukowych jest ogromna, a ich prezentacja przybiera różne formy, m.in. artykułów przedstawiających postępy wiedzy, nowe dane, substancje i odczynniki czy oprogramowanie, ale także własność intelektualną oraz znakomicie wykształconych młodych naukowców. Organizacje dostarczające funduszy, instytucje zatrudniające naukowców oraz sami badacze oczekują i potrzebują właściwych metod oceny jakości i wpływu wyników badań naukowych. Jest zatem konieczne, aby wyniki te były oceniane precyzyjnie i mądrze.

Journal Impact Factor (miara oddziaływania lub czynnik wpływu czasopisma) używany jest często jako podstawowe kryterium, za pomocą którego porównuje się wyniki badań poszczególnych naukowców i instytucji. Journal Impact Factor, szacowany przez Thomson Reuters, stworzony został pierwotnie jako narzędzie, które miało ułatwić pracownikom bibliotek wybór czasopism do zakupów, a nie do oceny wartości badań naukowych zawartych w zamieszczanych artykułach. Mając to na uwadze, należy bezwzględnie przyjąć do wiadomości, że Journal Impact Factor jako narzędzie oceny badań ma wiele dobrze udokumentowanych niedostatków. Te ograniczenia to:

A) w znacznym stopniu nierównomierne zamieszczanie cytowań w obrębie rozmaitych czasopism, a więc interpretacja - wypaczona [1-3];

B) właściwości Journal Impact Factor różniące się w rozmaitych obszarach (specjalnościach) wiedzy; jest to wypadkowa mieszaniny wielu, znacznie różniących się między sobą, rodzajów publikacji, w tym zarówno prac prezentujących wyniki badań oryginalnych, jak i prac o charakterze przeglądowym [1,4];

C) Journal Impact Factors mogą być przedmiotem manipulacji (czy „rozgrywania”) poprzez dobór odpowiedniej polityki redakcyjnej [5];

D) brak przejrzystości oraz pełnej dostępności dla opinii publicznej danych, które wykorzystuje się do obliczania Journal Impact Factors [4, 6, 7].

Zamieszczamy poniżej szereg rekomendacji, które mają na celu udoskonalenie sposobu, w jaki ocenia się wyniki badań naukowych. W przyszłości przedstawianie wyników w inny sposób, niż w postaci artykułów naukowych, będzie miało rosnące znaczenie w procesie oceniania efektywności badań. Zasadniczym jednak elementem tej oceny pozostanie recenzowana publikacja. Nasze zalecenia skupiają się zatem głównie na obszarze prac naukowych publikowanych w czasopismach recenzowanych, lecz mogą i powinny znaleźć też szersze zastosowanie w odniesieniu do innych sposobów prezentacji, np. w postaci zbiorów danych ( $d a-$ tasets). Te zalecenia skierowane są pod adresem organizacji finansujących, instytucji badawczych, czasopism, organizacji bibliometrycznych oraz samych badaczy.

W sformułowanych zaleceniach powtarza się kilka zagadnień:
- potrzeba wyeliminowania posługiwania się cechami bibliometrycznymi czasopism (journal-based metrics), takimi jak Journal Impact Factors, w decydowaniu o finansowaniu, zatrudnianiu oraz promocji w nauce i przyznawaniu stopni naukowych;

- potrzeba oceniania badań w większym stopniu według ich własnej wartości, niż na podstawie tego, w jakim czasopiśmie publikowane są ich wyniki; oraz

- potrzeba korzystania z możliwości, jakie tworzą publikacje online (takich jak zmniejszenie zbędnych ograniczeń ilości słów, ilustracji czy odniesień w artykułach oraz odkrywania nowych wskaźników znaczenia i wpływu). Zdajemy sobie sprawę, że wiele organizacji finansujących, instytucji, wydawców i samych naukowców już sprzyja idei wypracowania lepszych metod oceniania wyników badań. Dzięki nim powstaje sprzyjająca atmosfera i poparcie dla tworzenia właściwszych i bardziej uzasadnionych zasad oceny prac badawczych, które mogłyby zostać przyjęte przez wszystkie zainteresowane strony.

Sygnatariusze San Francisco Declaration on Research Assessment popierają przyjęcie następujących zasad w ocenianiu badań naukowych:

\section{Zalecenia ogólne}

1. Nie należy stosować danych bibliometrycznych czasopism (journal-based metrics), takich jak Journal Impact Factors, jako zastępczej miary jakości poszczególnych artykułów naukowych, do oceniania wkładu konkretnych badaczy czy podejmowania decyzji o ich zatrudnieniu, promowaniu lub finansowaniu.

\section{Dla instytucji przyznających środki finansowe}

2. Należy jednoznacznie, w przejrzysty sposób formułować kryteria oceny wydajności naukowej (scientific productivity) aplikujących o przyznanie grantu i wyraźnie podkreślać, szczególnie początkującym badaczom, że zawartość merytoryczna pracy jest o wiele ważniejsza niż dane bibliometryczne (publication metrics) i nazwa (identity) czasopisma, w jakim praca się ukazała.

3. W celu oceny badań należy brać pod uwagę wartość i wpływ wszystkich sposobów przedstawiania wyników — również zbiorów danych (datasets) i oprogramowania (software) - jako uzupełnienia dla klasycznych artykułów oryginalnych, oraz udziałjakościowych mierników wpływu badań (qualitative indicators of research impact), jak oddziaływanie na politykę postępowania i wymiar praktyczny.

\section{Dla instytucji}

4. Należy jednoznacznie, w przejrzysty sposób formułować kryteria stosowane w podejmowaniu decyzji o zatrudnianiu, przyznawaniu stanowisk czy dalszej promocji. Należy też wyraźnie podkreślać, szczególnie początkującym badaczom, że zawartość merytoryczna pracy jest 
o wiele ważniejsza niż dane bibliometryczne i nazwa czasopisma, w jakim praca się ukazała.

5. W celu oceny badań należy brać pod uwagę wartość i wpływ wszystkich sposobów przedstawiania wyników badań (również zbiorów danych i oprogramowania), nie tylko oryginalnych prac badawczych, oraz udział jakościowych mierników wpływu, jak oddziaływanie na politykę postępowania i wymiar praktyczny.

\section{Dla wydawców}

6. Należy znacznie zmniejszyć podkreślanie Journal Impact Factor jako narzędzia promocji, najlepiej przez zaniechanie przedstawiania go, ew. przez ukazywanie go w kontekście innych stosowanych kryteriów badań bibliometrycznych (takich jak: 5-letni impact factor, Eigenfactor [8], SCImago [9], h-index h itp.), które dostarczają szerszego oglądu statusu czasopisma.

7. Należy udostępnić zestaw kryteriów stosowanych w odniesieniu do samej pracy naukowej (article-level metrics), aby zachęcić do zmiany w kierunku oceny opartej na treści naukowej artykułu, a nie na danych bibliometrycznych czasopisma, w którym się ukazał.

8. Należy promować odpowiedzialny stosunek do kwestii autorstwa, z dostarczeniem informacji o wkładzie każdego $z$ autorów w powstanie publikacji.

9. Niezależnie od tego, czy czasopismo ma charakter ogólnodostępny (open access) czy odpłatny (subscription-based), należy usunąć wszystkie zbędne ograniczenia odnoszące się do wykazów cytowanego piśmiennictwa i udostępnić je na zasadzie Creative Commons Public Domain Dedication [10].

10. Należy znieść bądź znacząco zmniejszyć ograniczenia ilości przytaczanych źródeł w pracach naukowych, a tam, gdzie jest to uzasadnione, wymagać raczej cytowania oryginalnych prac badawczych niż przeglądów piśmiennictwa, dla podkreślenia roli tych, którzy rzeczywiście dokonali odkryć i pierwsi je opublikowali.

\section{Dla organizacji dostarczających danych}

bibliometrycznych

11. Należy w sposób jawny i przejrzysty przedstawić dane i metody używane do obliczania danych bibliometrycznych.

12. Należy dostarczać dane w sposób pozwalający na nieograniczone ponowne wykorzystanie i umożliwić kom- puterowy dostęp do tych danych tam, gdzie to tylko jest możliwe.

13. Nieodpowiednia manipulacja wskaźnikami bibliometrycznymi nie powinna być tolerowana, trzeba jednoznacznie określić, co jest niewłaściwą manipulacją i jakie środki zostaną przedsięwzięte, aby z tym walczyć.

14. Należy brać pod uwagę różnorodność rodzajów artykułów (np. prace przeglądowe versus prace oryginalne) oraz różnorodność dziedzin nauki (obszarów tematycznych) w każdym przypadku stosowania, kompilowania lub porównywania danych bibliometrycznych.

\section{Dla badaczy}

15. Osoby powołane do gremiów wydających decyzje o przyznawaniu funduszy, zatrudnianiu badaczy i ich awansowaniu powinny dokonywać ocen na podstawie wartości osiąganych wyników, a nie danych bibliometrycznych.

16. Gdziekolwiek to właściwe, należy cytować prace oryginalne, a nie przeglądy piśmiennictwa, aby przypisać właściwą rolę tym, którym się to rzeczywiście należy.

17. Należy wykorzystywać całą gamę kryteriów i ocen oraz osobnych komentarzy dla ukazania oddziaływania poszczególnych opublikowanych artykułów i innych opisów wyników badań [11].

18. Należy kwestionować praktykę niewłaściwego wykorzystywania Journal Impact Factors do oceny badań naukowych, a wspierać i rozpowszechniać sposoby opierające się na wartości i oddziaływaniu konkretnych wyników badań.

\section{Piśmiennictwo}

1. Adler R, Ewing J, Taylor P. Citation statistics. A report from the International Mathematical Union (2008). www.mathunion.org/publications/report/citationstatistics.

2. Seglen PO. Why the impact factor of journals should not be used for evaluating research. BMJ 1997; 314: 498-502.

3. Editorial. Not so deep impact. Nature 2005; 435: 1003-1004.

4. Vanclay JK. Impact Factor: Outdated artefact or stepping-stone to journal certification. Scientometrics 2012; 92: 211-238.

5. The PLoS Medicine Editors. The impact factor game. PLoS Med 2006; 3(6): e291 doi:10.1371/journal.pmed.0030291.

6. Rossner M, Van Epps H, Hill E. Show me the data. J. Cell Biol. 2007; 179, 1091-1092.

7. Rossner M, Van Epps H, Hill E. Irreproducible results: a response to Thomson Scientific. J Cell Biol. 2008; 180, 254-255.

8. http://www.eigenfactor.org/.

9. http://www.scimagojr.com/

10. http://opencitations.wordpress.com/2013/01/03/open-letter-to-publishers.

11. http://altmetrics.org/tools/ 